\title{
KEMAMPUAN KONEKSI MATEMATIS \\ DALAM PENYELESAIAN MASALAH SPLDV PADA SISWA SMP
}

\author{
Bisri Zainudin ${ }^{1}$, Arohman Taufik ${ }^{2}$, Teguh Wibowo ${ }^{3}$ \\ bisrizainudin179@gmail.com, omenarhoman10@gmail.com, twibowo@umpwr.ac.id \\ ${ }^{1,2}$ SMK YPE Sawunggalih Kutoarjo, ${ }^{3}$ Universitas Muhammadiyah Purworejo
}

\begin{abstract}
This research aims to describe the mathematical connection in problem solving. Metode of qualitative research. The subject of this study were two ninth graders of junior high school in with a purposive technique. The research instrument was a mathematical connection test problem. The data analysis technique uses three stages, namely data reduction, data presentation, and drawing conclusions. The results showed that students complate aspects of mathematical connections, namely: Aspects of mathematical connections in mathematical problems such as: Students understand the relationship between existing mathematical topics by writing down the equation model as ideas of the problems. Students are able to find the relationship between existing procedures and other procedures in representation with the equivalent concept shown by writing the twovariable linear system material equation. Students apply the relationship between mathematics, and between mathematical material with mathematical material by finding the value of equations. Students are able to use mathematical connections with mathematics or other fields of science using mathematics with economics to determine the number of purchases with capital, and aspects of mathematical connections with everyday life, namely, Students use procedures and concepts from one another according to the question data. The ability of students to use mathematics in everydaylife in the context of buying and selling using capital, amount, profit. So, as a whole the mathematical connection ability of junior high school students complate the indicators andinto the high connection category.
\end{abstract}

Keywords: mathematical connection, two-variable linear system material, connection aspects

\footnotetext{
Abstrak

Penelitian ini bertujuan untuk mendeskripsikan koneksi matematis dalam penyelesaian masalah. Metode penelitian adalah kualitatif. Subjek penelitian adalah dua siswa kelas IX SMP dengan teknik purposive. Instrumen penelitian berupa soal tes koneksi matematis. Teknik analisis data menggunakan tiga tahapan yaitu reduksi data, penyajian data, dan penarikan kesimpulan. Hasil penelitian menunjukkan bahwa siswa memenuhi aspek koneksi matematis, yaitu: a) Aspek koneksi matematis dalam masalah matematika seperti: 1) siswa memahami hubungan antara topik matematika yang ada dengan menuliskan model persamaan sebagai ide-ide dari soal. 2) siswa mampu mencari hubungan prosedur yang ada dengan prosedur yang lain dalam representasi dengan konsep yang ekuivalen yang ditunjukkan dengan menuliskan persamaan yang SPLDV. 3) siswa menerapkan hubungan antar matematika, dan antar materi matematika dengan materi matematika dengan mencari nilai dari persamaan. 4) siswa mampu menggunakan
} 
koneksi matematis dengan matematika atau ilmu bidang lainnya dengan menggunakan matematika dengan bidang ilmu ekonomi untuk menentukan jumlah pembelian dengan modal, dan b) Aspek koneksi matematis dengan kehidupan sehari-hari, yaitu: 1) siswa menggunakan prosedur dan konsep yang satu dengan yang lain sesuai data soal. 2) kemampuan siswa menggunakan matematika dalam kehidupan sehari-hari dalam konteks jualbeli dengan menggunakan modal, jumlah, keuntungan. Jadi, secara keseluruan kemampuan koneksi matematis siswa SMP memenuhi indikator dan masuk kategori koneksi tinggi.

Kata kunci: koneksi matematis, SPLDV, aspek koneksi

\section{ARTICLE HISTORY:}

Received: 2019-08-30, Revised: 2019-09-05,

Accepted: 2019-09-06, Onlinefirst: 2019-09-07

\section{PENDAHULUAN}

Kemampuan matematika dalam menghubungkan antara satu materi dengan materi lainnya adalah kemampuan koneksi matematis. Adanya kemampuan koneksi matematika memungkinkan siswa mampu menghubungkan keterkaitan antara konsep yang diperoleh secara terpisah untuk digunakan atau diaplikasikan pada konteks yang nyata sehingga dapat memberikan makna yang lebih baik bagi siswa. Serta diharapkan mampu membangkitkan minat belajar siswa terhadap matematika. Kemampuan koneksi matematis sebagai salah satu kemampuan seseorang dalam menyajikan hubungan internal maupun eksternal matematika, seperti koneksi antara materi matematika, koneksi dengan disiplin ilmu lain, serta koneksi dalam kehidupan sehari-hari (Warih, 2016).

Kemampuan koneksi matematis di atas menunjukkan bahwa kemampuan koneksi matematis merupakan kemampuan yang penting untuk dikembangkan pada siswa sekolah menengah. Kurangnya kemampuan siswa dalam koneksi matematis adalah salah satu penyebab timbulnya kesulitan dalam menyelesaikan sebuah persoalan yang berakibat rendahnya kemampuan matematika. Menurut Peraturan Mendiknas No. 23 tahun 2006, tentang standar kelulusan siswa salah satunya disebutkan bahwa mempelajari matematika di SMP standar yang diharapkan adalah siswa menunjukkan kemampuan berpikir logis, kritis, kreatif dan inovatif, menunjukkan kemampuan belajar secara mandiri sesuai potensi yang dimilikinya dan menunjukkan kemampuan menganalisis dan memecahkan masalah dalam kehidupan sehari-hari. Koneksi matematis adalah bagian penting yang harus mendapatkan penekanan pada setiap 
jenjang pendidikan (NCTM dalam Kusmanto \& Marliyana, 2014).

Kemampuan koneksi matematis adalah tingkat kemampuan siswa untuk mengaitkan materi matematika dengan materi matematika. Hubungan matematika dengan ilmu pengetahuan lain, hubungan matematika dengan kehidupan nyata. Menurut Bahr \& Garcia (Sudirman, 2017), kesulitan koneksi matematis siswa adalah suatu hambatan yang dialami siswa dalam menyelesaikan soal, karena siswa mengalami hambatan dalam menghubungkan antara berbagai representasi serta konsep-konsep matematika secara internal yaitu berhubungan dengan matematika itu sendiri ataupun secara eksternal yaitu matematika dengan bidang lain baik bidang studi lain maupun kehidupan sehari-hari.

Dari pernyataan sebelumnya tentang pentingnya koneksi matematis memungkinkan siswa dapat menghubungkan keterkaitan konsep-konsep yang telah dipelajari secara bertahap sehingga dapat mengaplikasikan ke konsep yang nyata. Supaya tidak hanya mengetahui namun juga dapat menerapkan dalam konsep yang telah dipelajari sebelumnya. Gambaran umum dalam koneksi matematis adalah kemampuan menghubungkan materi-materi bahasan yang satu dengan bahasan yang lain sehingga ada keterkaitan. Hal tersebut sangat penting dalam mempelajari penyelesaian soal SPLDV yang dipelajari memiliki keterkaitan dan memiliki urutan dalam penyelesaian materi tersebut. Sehingga kemampuan koneksi matematis dalam penyelesaian soal sangat penting bagi siswa.

Beberapa penelitian yang telah dilakukan dengan kemampuan koneksi. Siswa dapat memahami masalah matematika secara detail. Namun, hasil tes kemampuan koneksi yang dilakukan oleh 3 siswa, hanya 1 siswa yang koneksi matematis berada pada kategori tinggi, sedangkan 2 siswa yang lain berada pada kategori cukup (Agil, 2018). Hasil penelitian lain tentang koneksi matematis memiliki kemampuan tinggi, sedang, dan rendah memiliki kemampuan koneksi matematis yang berbeda-beda. Subjek berkemampuan tinggi memiliki kesulitan dalam mengenali konsep prosedur matematika (Karyanto dan Mampouw, 2018).

Berdasarkan uraian di atas tujuan dalam penelitin ini untuk mendeskripsikan kemampuan koneksi matamatis siswa SMP dalam pembelajaran matematika, terutama pada berbagai macam tingkatan kemampuan koneksi matematis oleh siswa SMP yang terfokus pada siswa dengan nilai matematika sama atau diatas 80 . 


\section{METODE PENELITIAN}

Metode penelitian yang digunakan adalah penelitian kualitatif atau sering disebut juga penelitian naturalistik karena penelitiannya dilakukan pada kondisi yang alamiah atau natural setting (Sugiyono, 2017). Penelitian kualitatif merupakan suatu penelitian yang bermaksud untuk memahami fenomena tentang apa yang dialami oleh subjek penelitian misalnya perilaku, persepsi, motivasi, tindakan, dan lain-lain, dengan cara deskripsi dalam bentuk kata-kata dan bahasa, pada suatu konteks khusus yang alamiah dan dengan memanfaatkan berbagai metode alamiah (Moleong, 2014). Penelitian ini dilakukan di salah satu SMP di Kabupaten Purworejo pada bulan Mei-Juli 2019. Subjek ditentukan dengan menggunakan teknik purposive. Purposive adalah teknik pengambilan subjek sumber data dengan pertimbangan tertentu (Sugiyono, 2017). Subjek dalam penelitian adalah dua siswa yang memiliki nilai dalam pelajaran matematika sama atau di atas 80 . Pengumpulan data dalam penelitian ini dengan pemberian tes, wawancara, dan catatan lapangan (Sugiyono, 2017). Sumber data dalam penelitian ini adalah sumber primer. Sumber primer adalah sumber data yang langsung memberikan data kepada pengumpul data (Sugiyono, 2017). Dibagi menjadi dua data yaitu data primer yang berupa hasil tes matematis siswa dan data sekunder yang berupa data hasil wawancara serta catatan lapangan. Teknik analisis data yang digunakan melaui tiga tahap, yaitu data reduction, data display, dan conclusion drawing/verification (Sugiyono, 2017).

Instrumen soal seperti berikut.

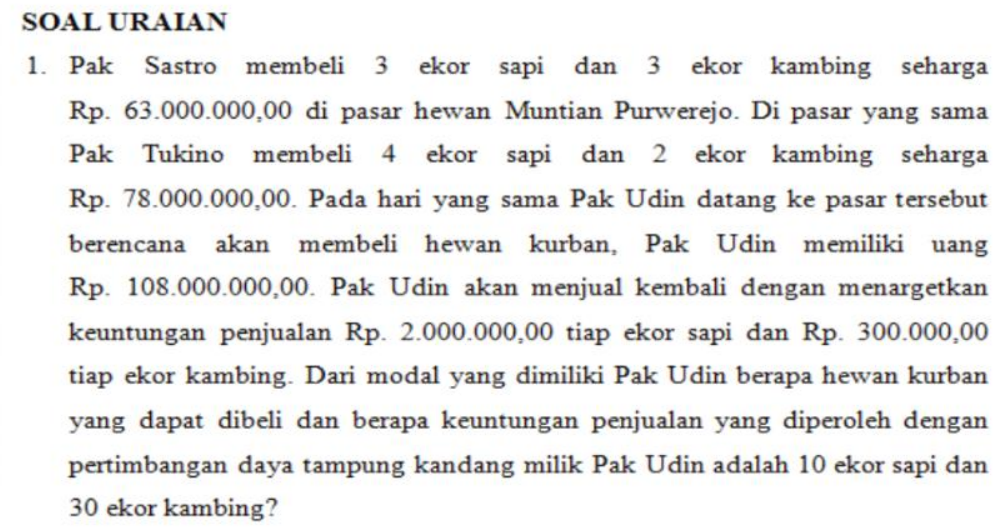

Gambar 1. Soal koneksi Matematis 


\section{HASIL PENELITIAN}

Langkah pertama yang dilakukan siswa dalam menyelesaikan soal tes yang ada, siswa menuliskan informasi yang ada berupa permisalan dalam menuliskan data dalam lembar jawab. Hasil jawaban siswa dalam menuliskan informasi yang ada dan dalam membuat permisalan dalam model matematika dapat dilihat pada gambar berikut.

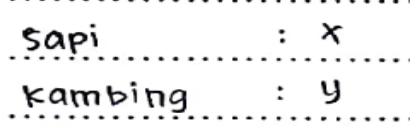

Gambar 2. Hasil Jawaban dalam Permisalan

Dari hasil di atas menunjukan bahwa siswa mampu dalam memahami keterkaitan data yang ada dalam soal menjadi data untuk menyelesaikan permasalahan yang ada atau dapat mengambil informasi yang ada berupa ide-ide dari soal untuk menyelesaikan masalah dengan siswa memilih menggunakan permisalan dalam mengerjakan soal yang ada sehingga mempermudah dalam penyelesaiannya. Berdasarkan perkerjaan di atas dapat diketahui bahwa siswa mampu memahami antar topik matematika. Hal tersebut dibuktikan dengan siswa mampu menunjukan apa yang dituliskan dalam cara permisalan didalam persamaan matematika.

Selanjutnya hasil perkerjaan yang didapat pada lembar jawab siswa. Dari hasil yang tertulis siswa mampu menuliskan informasi yang didapat dari soal yang digunakan siswa menjadi sebuah persamaan menjadi $3 x+3 y=63.000 .000$ dan $4 x+2 y=$ 78.000.000 yang ada seperti pada hasil tes berikut.

$$
\begin{aligned}
& 3 x+3 y=63.000 .000 \\
& 4 x+2 y=78.000 .000
\end{aligned}
$$

Gambar 3. Hasil Jawaban Siswa

Berdasarkan hasil di atas siswa mampu menjelaskan dan memahami apa langkah yang dikerjakan dan mengerti masalah yang dihadapi pada soal tersebut. Dengan hasil jawaban di atas dapat diketahui bahwa siswa mampu mencari hubungan prosedur yang ada dengan prosedur yang lainnya dalam representasi dengan konsep yang ekuivalen. Hal tersebut dibuktikan dari hasil jawaban siswa yang ada dengan prosedur dari soal yang diperoleh informasi dalam menuliskan permisalan dengan prosedur dalam mengubah informasi dari soal menjadi model matematika dan sebuah persamaan yang tepat. 
Tahap selanjutnya pada jawaban siswa yang melakukan penyamaan salah satu variabel yang ada untuk mencari nilai variabel yang dicari. Hasil yang dikerjakan oleh siswa. Siswa menggunakan operasi perkalian dalam bentuk persamaan $3 x+3 y=$ 63.000.000 dikalikan dengan 2 dan $4 x+2 y=78.000 .000$ dikalikan dengan 3 sehingga diperoleh nilai variabel yang sama adalah nilai variabel $y$ yang sama pada kedua hasil persamaan yang dikalikan. Siswa dapat menggunakan metode eliminasi untuk mencari nilai sesuai dengan hasil yang didapat pada hasil tes berikut.

\begin{tabular}{|c|c|c|}
\hline $3 x+3 y=63.000 .000$ & $\times 2$ & $6 x+6 y=126.000 .000$ \\
\hline $4 x+2 y=78.000 .000$ & $\times 3$ & $12 x+6 y=234.000 .000$ \\
\hline & & $\begin{array}{l}=-108.000 .000 \\
\ldots \ldots \cdots \cdots \cdots \cdots \cdots \cdots \cdots \cdots \cdots\end{array}$ \\
\hline & & $=-108.000 .000$ \\
\hline & & -6 \\
\hline & & $x=18.000 .000$ \\
\hline
\end{tabular}

Gambar 4. Hasil Jawaban Siswa

Dari hasil di atas dapat diperoleh informasi bahwa siswa mengetahui cara untuk melakukan perkalian untuk mencari nilai variabel yang dicari menggunakan metode eliminasi dan langkah yang tepat. Berdasarkan hasil jawaban di atas dapat diketahui bahwa siswamampu menerapkan hubungan antara matematika dan dengan antara materi matematika. Hal tersebut dibuktikan dengan siswa dapat mencari nilai $x$ atau harga dari salah satu variabel yang dicari dan melakukan perhitungan yang sesuai.

Siswa melakukan langkah selanjutnya yaitu mencari nilai $y$ dengan cara memasukan nilai $x$ yang didapat dan menggantikannya pada salah satu persamaan yaitu $4 x+2 y=78.000 .000$ sehingga didapat nilai y yang dicari menggunakan metode yang sesuai dan tepat dalam mencari nilai. Hasil yang didapat pada hasil tes berikut.

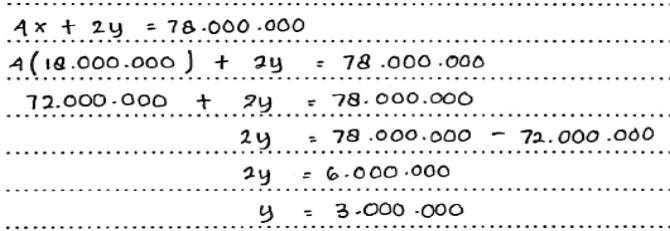

Gambar 5. Hasil Jawaban Siswa

Dari hasil di atas dapat diperoleh informasi bahwa siswa mengatahui langkah yang harus dikerjakan untuk mencari nilai dengan menggunakan metode subtitusi. Langkah yang dilakukan sesuai dengan apa yang dikerjakan siswa pada lembar jawab. Berdasarkan hasil jawaban di atas dapat diketahui bahwa siswa mampu menggunakan koneksi matematis dengan matematika atau ilmu bidang lainnya. Hal tersebut 
dibuktikan dengan siswa mampu mengoperasikan dan menggunakan kemampuan menghubungkan konsep yang ada dengan konsep yang lainnya sesuai apa yang dicari yang dilakukan subjek seperti menggunakan hasil dari perhitungan menggunakan metode eliminasi untuk mencari nilai variabel menggunakan metode subtitusi.

Selanjutnya siswa melakukan perhitungan untuk mencari jumlah yang dapat dibeli dengan menggunakan modal yang ada dibagi dengan harga satuan nilai $x$ yang ada. Sehingga dapat memperoleh dengan menuliskan hasil yang didapat dari soal seperti pada hasil tes berikut.

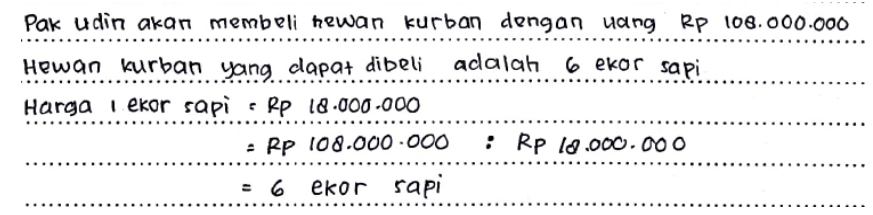

Gambar 6. Hasil Jawaban Siswa

Dari hasil di atas diperoleh informasi bahwa siswa menggunakan nilai yang diperoleh dari perhitungan sebelumnya untuk menentukan atau mencari jumlah yang bisa diperoleh. Berdasarkan hasil jawaban di atas dapat diketahui bahwa siswa mampu menggunakan prosedur dan konsep yang satu dengan lainnya. Hal tersebut dibuktikan dengan adanya perhitungan untuk mencari hasil yang ada dengan data yang dimiliki untuk mencari nilai.

Selanjutnya siswa mengerjakan pada bagian penyelesaian dengan menggunakan jumlah yang dapat dibeli untuk menentukan berapa besar keuntungan yang didapat dengan mengalikan target keuntungan dengan jumlah yang dapat dibeli. Kemudian hasil keseluruhan dari perhitungan yang ada digunakan untuk menjawab pertanyaan dari soal yang menjadi kesimpulan jawaban dari siswa.Hasil yang didapat dari hasil tes berikut.

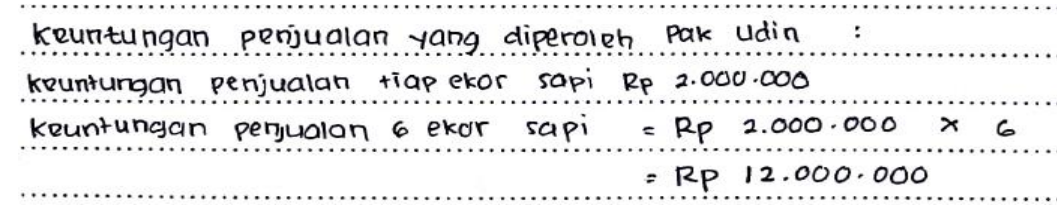

Jadi, hewan kurban yang dapat dibeli pak udin dengan modal Rp 100.000 .000 sebanyak 6 ekor sapi. Keuntungan penjualan yang diperoleh pak udin adalah Rp 12.000.000

Gambar 7. Hasil Jawaban Siswa

Dari hasil di atas diperoleh informasi bahwa siswa dapat memahami maksud dan tujuan dari soal untuk mencari berapa keuntungan yang diperoleh yang paling maksimal 
dengan data hasil perhitungan yang ada. Sehingga diperoleh kesimpulan yang sesuai dengan pertanyaan dari soal. Berdasarkan hasil jawaban, siswa mampu menggunakan matematika dalam kehidupan sehari-hari. Hal tersebut dibuktikan dengan kemampuan siswa dalam mengkaitkan dengan perhitungan yang ada dengan kejadian yang ada atau berkaitan dengan kehidupan sehari-hari.

\section{PEMBAHASAN}

Berikut akan dijelaskan tentang kemampuan koneksi matematis dalam penyelesaian masalah SPLDV pada siswa berdasarkan hasil tes koneksi matematis, catatan lapangan, dan wawancara. Masalah matematika tentang masalah SPLDV untuk mencari harga beli tiap ekor untuk mendapatkan jumlah yang dapat dibeli dengan modal yang ada dan mencari berapa jumlah keuntungan yang maksimal yang diperoleh jika habis terjual yang menjadi ide-ide dalam soal. Pada saat mengerjakan soal tersebut siswa mampu memahami informasi dari soal, sehingga siswa memperoleh data-data informasi yang digunakan untuk melakukan permisalan dengan siswa menuliskan sapi $=x$ dan kambing $=y$ untuk mencari dan memahami informasi dari soal.

Siswa dapat mengkaitkan atau menghubungkan informasi yang terdapat dari soal menjadi sebuah permisalan untuk mengerjakan soal. Siswa mengunakan informasi yang diketahui pada masalah yang diberikan kemudian menghubungkan semua informasiinformasi tersebut dengan menggunakan konsep-konsep matematika secara tepat (Diana, 2017). Siswa mampu memahami hubungan antara topik matematika dengan baik dari hasil jawaban siswa mampu menuliskan informasi yang didapat dari soal untuk menuliskan permisalan dengan benar. Sehingga siswa dapat memahami hubungan antara topik matematika dengan baik.

Kemudian siswa mampu mencari hubungan prosedur yang ada dengan prosedur yang lain dalam representasi dengan konsep yang ekuivalen. Siswa dalam mengerjakan soal yang diujikan menggunakan data yang ada seperti 3 ekor sapi dan 3 ekor kambing seharga Rp. 63.000.000 ditulis pada lembar siswa dengan $3 x+3 y=63.000 .000$, untuk 4 ekor sapi dan 2 ekor kambing seharga Rp.78.000.000 ditulis menjadi $4 x+$ $2 y=78.000 .000$. Siswa terlihat dapat menggunakan dengan baik dan secara sistematis yang baik. Hal ini menunjukan hubungan yang ada dalam berbagai konsep dan prosedur yang ada dengan prosedur yang lain dalam representasi dalam konsep 
yang ekuivalen. Siswa tidak mengalami kesulitan dalam mengaitkan dalam persamaan yang sesuai dengan menggunakan representasi konsep yang ekuivalen pada penggunaan konsep. Sesuai dengan persamaan yang digunakan oleh siswa dengan mampu menggunakan hubungan persamaan dan prosedur yang ada dengan prosedur yang lain dalam representasi dalam konsep yang ekuivalen sehingga dapat mencari data yang sesuai. Menemukan keterkaitan prinsip matematika pada masalah dengan prinsip yang diperlukan untuk menjawab pertanyaan dan prosedur matematika matematika yang telah dipahami (Romli, 2016). Jadi siswa mampu mencari hubungan yang ada dalam berbagai konsep dan prosedur yang ada dengan prosedur yang lain dalam representasi dalam konsep yang ekuivalen dengan baik.

Siswa memiliki 2 persamaan yang ada yaitu $3 x+3 y=63.000 .000$, dan $4 x+$ $2 y=78.000 .000$ dari persamaan tersebut siswa menyamakan kedua persamaan dengan cara mengalikan dengan tujuan untuk menyamakan salah satu variabel. Variabel yang disamakan oleh siswa adalah variabel $y$. Hal ini menjadi kemampuan siswa dalam menggunakan konsep dalam materi matematika yang ada untuk mencari salah satu nilai dari variabel dengan menggunakan persamaan yang diketahui. Sehingga nilai variabel yang dicapai dapat diketahui $(x=18.000 .000)$. Menggunakan hubungan prinsip matematika satu dengan yang lainnya untuk menyelesaikan masalah serta menggunakan keterkaitan konsep dengan prosedur dan operasi hitung untuk menyelesaikan masalah (Romli, 2016). Hal ini membuktikan bahwa siswa telah mencapai indikator koneksi matematis yang berupa siswa mampu menerapkan hubungan antar matematika dan antar materi matematika dengan materi matematika.

Setelah dapat mencari hasil dari nilai $x$ yang temukan dengan menggunakan metode eliminasi selanjutnya subjek melakukan penggantian nilai $x$ pada salah satu persamaan untuk menentukan nilai $y$ yang dicari dengan menggunakan metode subtitusi sebagai cara mencarinya. Pada hasil yang ada pada lembar jawab dari siswa menunjukan hasil yang sama dalam mencari nilai dari variabel yang lain, dengan diketahui nilai dari salah satu variabel yang diperoleh dari perhitungan dua persamaan yang diketahui. Hasil nilai $x$ sebelumnya adalah 18.000.000 dimasukan ke dalam persamaan $4 x+2 y=78.000 .000$ sehingga diperoleh $y=3.000 .000$. Dari hasil perhitungan untuk mencari nilai variabel yang lain siswa mampu menggunakan metode subtitusi dengan benar untuk mencari nilai variabel yang dicari. Siswa mengkoneksikan 
ide yang satu dengan yang lain sehingga menghasilkan suatu keterkaitan yang menyeluruh dalam menyelesaikan soal cerita (Zulfa, 2018). Hal ini membuktikan bahwa siswa telah mencapai indikator koneksi matematis yang berupa mengunakan koneksi matematis dengan matematika atau ilmu bidang lainnya, artinya siswa mampu menghubungkan metode yang ada dengan metode yang lain untuk mendapatkan nilai.

Selanjutnya dari jawaban siswa diperoleh informasi untuk mencari jumlah yang dicari keduanya menggunakan jumlah modal yang dimiliki dibagi dengan harga satuan dari $x$ atau $y$, sehingga diperoleh jumlah yang dapat dibeli. Hal ini sesuai bahwa kemampuan koneksi matematis antar konsep sangat diperlukan dalam memecahkan masalah matematika karena materi matematika memiliki keterkaitan antara satu konsep dengan konsep yang lain (Prihastanto dan Fitriyani,2017). Siswa dapat menggunakan operasi yang sesuai dalam menggunakan konsep perhitungan yang ada dengan menggunakan informasi data yang didapat dari soal, sehingga siswa mampu menggunakan prosedur yang ada dengan baik. Hal ini membuktikan bahwa siswa mampu menggunakan prosedur dan konsep yang satu dengan yang lain.

Dari hasil perkerjaan siswa pada bagian akhir yaitu mencari berapa jumlah hewan yang dapat dibeli dan berapa keuntungan yang dapat diperoleh secara maksimal, siswa membagi jumlah modal yang dimiliki dengan harga beli tiap ekor $\left(\frac{108.000 .000}{18.000 .000}=6\right)$ dengan hasil yang diperoleh dikalikan dengan target keuntungan $(6 \times 2.000 .000=$ 12.000.000), siswa memilih hasil yang maksimal dalam penjualan. Kemampuan mampu mencari target keuntungan yang didapat dengan mengunakan perhitungan dan mampu menentukan kesimpulan yang sesuai dengan pertanyaan yang ada. Siswa mampu menggunakan matematika dalam kehidupan sehari-hari dengan menyelesaikan soal secara sistematik dan teliti. Koneksi matematis berfungsi sebagai alat bantu untuk menyelesaikan masalah dalam kehidupan sehari-hari (Karyanto dan Mampouw, 2018). Siswa dalam menentukan hasil dari kesimpulan harus memahami proses perhitungan yang tepat dan sesuai dengan apa yang ada pada soal sehingga siswa mampu menggunakan matematika dalam kehidupan sehari-hari yang pada khususnya pada masalah SPLDV dalam soal cerita. Dengan demikian siswa telah mencapai mampu menggunakan matematika dalam kehidupan sehari-hari.

Berdasarkan data di atas diperoleh bahwa, siswa telah mencapai beberapa keterampilan dalam koneksi matematis. Adapun keterampilan yang telah dicapai oleh 
siswa antara lain: 1) memahami hubungan antara topik matematika yaitu dengan membuat permisalan yang sesuai dengan informasi yang didapat dari soal; 2) mampu mencari hubungan prosedur yang ada dengan prosedur yang lain dalam representasi dengan konsep yang ekuivalen yaitu dengan menggunakan persamaan yang diperoleh dari soal untuk mencari salah satu nilai dengan menggunakan 2 persamaan yang diketahui sehingga memperoleh nilai yang dicari; 3) menerapkan hubungan antar matematika, dan antar materi matematika dengan materi matematika yaitu dengan mengunakakan hasil data yang dimiliki untuk menentukan nilai variabel yang lain sesuai dengan materi yang ada dalam matematika; 4) mengunakan konsep matematika dengan matematika atau ilmu bidang lainnya yaitu dengan menggunakan konsep yang sesuai untuk mencari nilai jika salah satu nilai dari variabel sudah dicari sebelumnya untuk mencari nilai variabel yang lainnya; 5) mengunakan prosedur dan konsep yang satu dengan yang lain yaitu dengan melakukan operasi perhitungan dengan data yang diperoleh dari perhitungan sebelumnya dan juga menggunakan data informasi yang ada pada soal tersebut; dan 6) mampu menggunakan matematika dalam kehidupan seharihari yaitu dapat menerapkan perhitungan yang sesuai informasi yang ada serta dapat menarik kesimpulan sesuai dengan pertanyaan yang ada pada soal.

Dalam penelitian ini peneliti menduga dan berargumen jika kemampuan koneksi matematis rendah itu siswa dapat memenuhi indikator 2. Kemampuan koneksi matematis sedang itu dapat memenuhi minimal indikator 5, dengan syarat disini jika memiliki kemampuan sedang dapat memenuhi 3-5 indikator yang digunakan di atas. Kemampuan koneksi matematis tinggi itu dapat memenuhi dari indikator yang ada dari indikator 7, jika dalam indikator yang digunakan terpenuhi lebih dari 5 indikator yang ada penulis mengkategorikan sebagai kemampuan koneksi tinggi.

Dengan demikian dari soal tes koneksi yang digunakan, siswa dapat memenuhi 6 indikator dari 7 indikator yang digunakan dan semua siswa memenuhi indikator yang dicapai pada materi SPLDV. Sehingga dapat dikatakan secara keseluruhan bahwa siswa dalam menyelesaikan soal koneksi matematis materi SPLDV memenuhi indikator dan termasuk kategori tinggi. 


\section{SIMPULAN DAN SARAN}

Dari hasil di atas siswa dapat diambil kesimpulan bahwa siswa mampu menyelesaikan soal SPLDV dengan baik berdasarkan data yang ada siswa mampu memenuhi indikator koneksi matematis. Deskripsi data dan hasil pembahasan di atas mengenai kemampuan koneksi matematis dalam penyelesaian masalah SPLDV maka didapat kesimpulan siswa dapat mencapai indikator yang digunakan oleh peneliti tentang kemampuan koneksi matematis yaitu: 1) siswa mampu memahami hubungan antara topik matematika dengan mengubah informasi yang didapat dari soal dengan menjadikan ide-ide yang ada dalam soal menjadi informasi yang sesuai yaitu memisalkan $x$ dan $y$, sebagai variabel dalam permisalan; 2) siswa mampu mencari hubungan prosedur yang ada dengan prosedur yang lain dalam representasi dengan konsep yang ekuivalen dengan merubah informasi dari soal yang berupa data informasi dari soal cerita menjadi data yang digunakan untuk model persamaan dua variabel dalam bentuk $(a x+b y=c)$, untuk memodelkan persamaan yang ada; 3) siswa mampu menerapkan hubungan antar matematika dan antar materi matematika dengan materi matematika dengan siswa dapat menggunakan 2 persamaan yang ada untuk menyamakan salah satu variabel yang dicari untuk mengunakan metode eliminasi persamaan dengan mengalikan persamaan yang ada dengan bilangan asli $(N)$ agar terdapat nilai variabel yang sama; 4) siswa dapat mengunakan koneksi matematis dengan matematika atau ilmu bidang lainnya dengan kemampuan siswa mencari harga beli untuk kambing mengunakan data yang diperoleh dengan metode eliminasi untuk mencari nilai variabel yang dicari seperti variabel $y$ dan menggunakannya untuk mencari harga kambing dengan memasukkan ke dalam persamaan yang ada dimasukkan ke persamaan $4 x+2 y=78.000 .000$ maka diperoleh $y=3.000 .000$; 5) siswa mampu menggunakan prosedur dan konsep yang satu dengan yang lain yang menunjukkan bahwa jumlah yang dicari keduanya menggunakan jumlah modal yang dimiliki dibagi nilai variabel $x$ atau $y$, sehingga diperoleh jumlah yang dapat dibeli yaitu untuk variabel $x$ dan $y$; dan 6) siswa mampu menggunakan matematika dalam kehidupan sehari-hari yang dilakukan oleh siswa dalam menyelesaikan soal yang ada dengan menggunakan perhitungan yang sesuai dengan kaitannya logika dalam kehidupan sehari-hari dengan konteks dalam jual-beli yang digunakan untuk membeli dengan jumlah yang sesuai dengan modal yang dimiliki dan menjualnya dengan target 
keuntungan yang sesuai yaitu dari Rp.108.000.000 dapat membeli 6 ekor sapi dengan harga Rp. 18.000.000 serta akan menjual dengan keuntungan Rp. 2.000 .000 setiap ekornya maka dapat memperoleh keuntungan total penjualan Rp. 12.000.000.

Dari indikator-indikator yang ada di atas siswa telah memenuhi 2 aspek koneksi matematis yaitu: a) aspek koneksi matematis dalam masalah matematika dengan 4 indikator dan b) aspek koneksi matematis dengan kehidupan sehari-hari dengan 2 indikator yang dicapai. Sehingga secara keseluruan siswadapat memenuhi 6 indikator dan memiliki kemampuan koneksi matematis yang termasuk kategori tinggi karena telah memenuhi lebih dari 5 indikator dari koneksi matematis.

Peneliti dapat memberikan saran-saran sebagai berikut.

1. Bagi Guru sebaiknya lebih mendalami kemampuan yang dimiliki oleh siswa pada khususnya kemampuan koneksi matematis terhadap materi SPLDV dan materi lainnya.

2. Bagi siswa diharapkan mampu lebih melatih kemampuan koneksi matematis dalam menyelesaikan masalah matematika, koneksi matematis sangat penting bagi siswa dalam menyelesaikan soal terutama pada soal uraian yang dalam penyelesaiannya memiliki beberapa langka penyelesaiannya.

3. Bagi penelitian selanjutnya disarankan dapat menentukan indikator yang sesuai dengan materi yang digunakan dengan siswa yang tepat, agar dapat memperoleh hasil yang maksimal

\section{DAFTAR PUSTAKA}

Arif. N. A. 2018. Analisis Kemampuan Koneksi Matematis Siswa SMP pada Materi Sistem Persamaan Linier Dua Variabel. Suska Journal of Matematics Education, Volume 4, Nomor 1, 2018, Halaman 59-64.

Diana, R.F., Irawan, E.B., \& Susiswo. 2017. Proses Koneksi Matematis Siswa Bergaya Kognitif Reflektif dalam Menyelesaikan Masalah Aljabar Berdasarkan Taksonomi SOLO. Jurnal Kajian Pembelajaran Matematika. Vol. 1, No. 1, p. 52-63.

Karyanto, P.S. \& Mampouw, H.L. 2018. Koneksi Matematis Materi Kubus dan Balok oleh Siswa SMP Kelas VIII. Jurnal Numeracy. Volume. 5, Nomor 1, Halaman 57-66. 
Kusmanto, H. \& Marliyana, I. 2014. Pengaruh Pemahaman Matematis Terhadap Kemampuan Koneksi Matematika Siswa Kelas VII Semester Genap SMP Negeri 2 Kasokandel Kabupaten Majalengka. Edukasi Matematika. Volume 3, Nomor 2, Halaman 61-75. ISSISWA 2086-3918.

Moleong, L.J. 2014. Metode Penelitian Kualitatif. Bandung: Remaja.

Peraturan Pemerintah. 2006. Peraturan Menteri Pendidikan Nasional Republik Indonesia nomor 23 tahun 2006 tentang Standar Kompetensi Lulusan Untuk Satuan Pendidikan Dasar dan Menengah. Diakses di https://bsiswapindonesia.org/id/wp-content/uploads/2009/04/Permen_23_2006.pdf pada 03 Maret 2019 pukul 10:33. Halaman 343.

Prihastanto, A.R. \& Fitriyani, H. 2017. Profil Kemampuan Koneksi Matematis Siswa SMP yang Bergaya Kognitif Reflektif-Impulsif dalam Menyelesaikan Soal Geometri. Didaktika. Vol. 23, No. 2, p. 89-98.

Romli, M. 2016. Profil Koneksi Matematis Siswa Perempuan SMA dengan Kemampuan Matematika Tinggi dalam Meyelesaikan Masalah Matematika. Journal of Mathematics Education, Science and Technology. Volume 1, Nomor 2, Halaman 144-163.

Sudirman. 2017. Analisis Kemampuan Koneksi Matematis Siswa SMP Pesisir ditinjau dari Gender. Prosiding Seminar Nasional Riset Kualitatif Terapan 2017. Halaman 131-139.

Sugiyono. 2017. Metode Penelitian Kualitatif. Bandung:Alfabeta.

Warih, S., Dwi, P., Parta, I. N., \& Rahardjo, S. 2016. Analisis Kemampuan Koneksi Matematis Siswa Kelas VIII pada Materi Teorema Pythagoras. Prosiding. ISSISWA: 2502-6526.

Zulfa, A. 2018. Kemampuan Koneksi Matematis Dalam Menyelesaikan Soal Cerita Bilangan Bulat di SMP N 2 Sungai Raya. Diakses di http://jurnal.untan.ac.id/index.php/jpdpb/article/download/26824/7567657494 pada tanggal 15 Agustus 2019. Halaman 11. 